\title{
Bir Üniversite Hastanesi Polikliniğine Başvuran Hastaların Sigara ve Alkol Bağımlılık Düzeylerine Etki Eden Faktörler
}

\author{
Factors Affecting Smoking and Alcohol Addiction Levels who Applied to a University \\ Hospital Polyclinic
}

Burkay YAKAR ${ }^{1}$, Edibe PİRINÇCí ${ }^{2}$

${ }^{1}$ Dr. Öğr. Üyesi. Fırat Üniversitesi Tip Fakültesi Aile Hekimliği Anabilim Dalı, ELAZIĞ

${ }^{2}$ Prof. Dr. Firat Üniversitesi Tip Fakültesi Halk Sağlığı Anabilim Dalı, ELAZIĞ

\section{Öz}

Amaç: Alkol ve sigara kullanımı toplum sağlığını tehdit eden önemli etkenlerin başında gelmektedir. Sigara ve alkol ile mücadelenin önünde ki en büyük engel ise bağımlılık yapıcı etkileri olarak gösterilmektedir. Çalışmamızda sigara ve alkol bağımlılık düzeyleri ve etkileyen faktörleri araştırmak amaçlanmıştır.

Gereç ve Yöntem: Kesitsel nitelikteki bu çalışma, bir üniversite hastanesinin aile hekimliği polikliniğine başvuran katılımcılar üzerinde yapıldı. Araştırmamızın bağımsız verileri sosyodemografik anket formu ile toplandı. Araştırmamızın bağımlı değişkenleri ise Fagerström Nikotin bağımlılık Testi ve CAGE testi ile elde edildi. Çalışmaya gönüllü olarak katılmayı kabul eden 181 kişiye anket uyguland. Sigara kullanan 64 kişi ve alkol kullanan 28 kişi değerlendirmeye alınd.

Bulgular: Nikotin bağımlılık derecesi erkeklerde, evlilerde, düşük eğitim seviyesi ve 15 yaşından önce sigaraya başlayanlarda daha yüksek saptandı. CAGE puanı ise 18 yaşından önce alkole başlayanlarda, erkeklerde, bekârlarda ve eğitim seviyesi yüksek olanlarda daha yüksek bulundu.

Sonuç: Alkol ve sigara bağımlılı̆̆ı halen önemli bir halk sağlı̆ğ sorunu olduğu ve mücadelede daha fazla etkin adımlar atılmasının gerektiği saptanmıştır.

Anahtar Kelimeler: Sigara, alkol, bağımlılık, CAGE, Fagerström

\section{Abstract}

Objective: Alcohol and smoking is one of the important factors that threaten public health. The biggest obstacle to the fight against smoking and alcohol is shown as their addictive effects. In our study, it was aimed to investigate the smoking and alcohol addiction levels and affecting factors of them.

Material and methods: This cross-sectional study was performed on participants who applied to the family medicine outpatient clinic of university hospital. The independent data of our study were collected by sociodemographic questionnaire. The dependent variables of our study were obtained by Fagerström Nicotine Addiction Test and CAGE test. The questionnaire forms were applied to 181 volunteer participants. A total of 64 smokers and 28 people using alcohol were included in the study.

Results: The degree of nicotine dependence was higher in males, married, lower education level and those who started smoking before age 15 years. The CAGE score was higher in those who started alcohol before age of 18 years, in males, in singles and in those with a high level of education.

Conclusion: It is determined that alcohol and cigarette addiction is still an important public health problem and more effective steps should be taken in the struggle.

Key Words: Smoking, alcohol, addiction, CAGE, fagerstrom.

\section{GİRIŞ}

Tütün kullanımı tüm dünyada en önemli sağlı̆̆ tehdit eden etkenlerin başında gelmekte ve her yil dünyadaki 10 ölümden birinin nedeni sigara olarak görülmektedir (1). Dünya Sağlık Örgütü verilerine göre sigara kullanım oranı dünya genelinde $\% 28$, Avrupa genelinde ise \% 35,3 olarak rapor edilmiștir (1). Ülkemizde ise 2012 yılında yapılan araştırmada erkeklerde sigara kullanımı \% 41,3 kadınlarda ise \% 15,2 olarak bildirilmiştir (2). Tüm ülkeler sigaranın sağlık üzerindeki etkilerine karşı mücadele yöntemleri başlatmışlardır. Sigaranın sağlık üzerinde ki negatif etkilerini azaltmanın en etkili yolunun sigarayı bırakmak olduğu ve sigara bırakmayı zorlaştıran en önemli etkenin ise nikotinin bağımlılık yapıcı etkisi olduğu belirtilmiştir $(3,4)$. Nikotin bağımlılı̆̆ teminin kolay olması, kullanımının yasal olması ve diğer bağımlılık yapıcı maddelere geçiş zemini hazırlaması nedeniylede en önemli madde bağımlılığı olarak görülmektedir (5). Sigarayı bırakmak isteyenlerin üçte ikisinin nikotin bağımlılığı nedeni

\begin{tabular}{|c|c|}
\hline İletişim: & $\begin{array}{l}\text { Dr. Burkay Yakar, Fırat Üniversitesi Tip Fakültesi Aile } \\
\text { Hekimliği Anabilim Dalı, } 23119 \text { Elazığ }\end{array}$ \\
\hline DOI: & $10.17517 /$ ksutfd.473723 \\
\hline
\end{tabular}

ile sigarayı bırakamadıkları bildirilmiştir $(6,7)$. Sigara ile tüm dünyada mücadele edilmesine rağmen sigaraya tekrar başlama oranlarının yüksek olduğu ve bağımlıların \% 70'inin tedavi sonrası tekrar sigaraya başladığının rapor edilmesi ve tütün ile mücadeleye rağmen yeterince başarılı olunamaması tütünün çok güçlü bağımlılık yaptığını göstermektedir $(8,9)$.

Alkol, sağlık risklerine, sosyal sorunlara ve bağımlılığa neden olması açısından önemli bir psikoaktif maddedir (10). Alkol bağımlılığı ise ciddi bireysel, toplumsal ve ekonomik sorunlara yol açan sık görülen bir bağımlılık tipidir (11). Alkol bağımlılığında tedaviye rağmen \% 60-90 oranında relaps görülmesi alkol ile mücadelenin nedenli zor olduğunu göstermektedir (12). Alkol kullanımı da sigara kullanımı gibi genç yaşta başlamaktadır. Dünya genelinde yapılan araştırmalara baktığımızda üniversite öğrencileri arasında yapılan 2 ayrı çalışmada \% 44-46 oranında alkol aşırı içme davranışı bildirilmiştir $(13,14)$. Ülkemizdeki duruma
Tel : 05059626932
E-Posta : byakar@firat.edu.tr
Geliş Tarihi : 23.10.2018
Kabul Tarihi : 25.03.2019 
baktığımızda ise 576 üniversite öğrencisi ile yapılan bir araştırmada \% 14 düzeyinde riskli alkol kullanımı saptanmıștır (15). Tip Fakültesi 6 sınıf öğrencileri arasında yapılan bir araştırmada ise alkol kullanma oranları \% 57, sorunlu alkol kullanma oranı ise \% 17 olduğu bildirilmiştir (16). Bu veriler bize alkol kullanımının bireyleri ve toplumu tehdit eden önemli bir halk sağllğı sorunu olduğunu göstermektedir.

Ciddi bir halk sağlığ problemi olarak bildirilen sigara ve alkol bağımlılığı devletlerin bu maddeler ile mücadelesine rağmen önemini korumaktadır. Sigara ve alkol bağımlılığ 1 tedavisinde pek yüz güldürücü sonuçlar elde edilememekte ve tedavi sonrası tekrar başlama oranları yüksek olabilmektedir. $\mathrm{Bu}$ bağlamda mücadele de en önemli nokta sigara ve alkol bağımlılığına zemin hazırlayan faktörlerin elimine edilmesidir. Çalışmamızda ilk olarak sigara ve alkol kullanıcılarının bağımlılıkdüzeylerinisaptamakamaçlanmıştır. Araştırmamızın diğer bir amacı ise bağımlılık düzeyine etki eden faktörleri saptamak ve bağımlılık düzeylerinin kişilerin sigara alkol kullanım tutumlarına etkileri araştırmak olarak belirlenmiştir. Çalışmamızdan elde edeceğimiz veriler ile madde bağımlılıkları ile mücadeleye katkı sağlamak amaçlanmıştır.

\section{GEREÇ VE YÖNTEM}

\section{Araştırmanın Tipi}

$\mathrm{Bu}$ çalışma; kesitsel türde tasarlanmıştır.

\section{Araştırmanı Yeri, Evren ve Örneklemi}

Araştırmamı üniversitemizin aile hekimliği polikliniğine başvuran ve araştırma kriterlerini karşılayan tüm hastaları kapsamaktadır. Araştırmamız Fırat Üniversitesi Girişimsel Olmayan Araştırmalar Etik Kurul onayı ve Fırat Üniversitesi Tip Fakültesi Hastanesi Başhekimliğinden yazılı izin alındıktan sonra Şubat-Nisan 2016 tarihlerinde üç ay süreyle Aile Hekimliği Polikliniğimize başvuran gönüllü tüm hastalara uygulanmıştır. Belirlenen sürede aile hekimliği polikliniğimize başvuran 201 kişiden sigara içtiğini beyan eden 64 kişiye fagerström nikotin bağımlılık testi, ve alkol kullandığını beyan eden 28 kişiye ise CAGE alkol kötüye kullanım testi uygulandı.

\section{Araştırmaya alınma ölçütleri}

18 yaş ve üzeri olma,

Sigara veya alkol kullanımı

Sigara ve Alkol bırakma tedavisi görmeme

Çalışmaya katılmaya gönüllü olma

\section{Araştırmaya alınmama ölçütleri}

İletişim problemi veya psikiyatrik tanısı bulunması

18 yaş altında olma

Anket formlarını yanlış veya eksik doldurma

\section{Veri Toplama Araçları}

Araştırmamızda ilk olarak katılımcıların gönüllülük esasını dikkat alarak bilgilendirilmiş gönüllü olur formu ile katılımcıların olurları talep edilmiştir. $\begin{array}{llll}\text { Literatür verileri taranarak hazırladı̆̆ımız } 25 & 25\end{array}$ soruluk sosyodemografik anket formu ile katılımcıların sosyodemografik özellikleri, sigara ve alkol kullanım özellikleri sorgulanmıştır.

Katılımcıların nikotin bağımlılık düzeylerini ölçmek için Fagerström Nikotin bağımlılık Testi uygulanmıştır (FNBT). Fagerström Nikotin bağımlılık Testi yaygın olarak kullanılan 6 sorudan oluşan bir testtir. Uysal ve ark. tarafından Türkçe versiyonu incelenmiş ve nikotin bağımlılığında ölçüm metodu olarak kullanılabileceği saptanmıştır (17). FNBT sonucunda bağımlılık puanı hesaplanmıștır. 0-3 puan arası düşük bağımlılık, 4-6 puan arası orta düzey bağımlılık, 7 ve üzeri puan ise yüksek nikotin bağımlılığı olarak kabul edilmiştir.

Katılımcıların alkol kötüye kullanım özelliklerini sorgulamak için alkol kullandığını beyan eden katılımcılara CAGE testi uygulanmıştır. CAGE, (Cut down, Annoyed, Guilty, Eyeopener) alkol kullanım bozukluğu olan bireyleri ayırt etmek amaciyla geliştirilmiş, dört sorudan oluşan, katılımcıların evet ve hayır şeklinde cevap verdiği kısa ve basit bir testtir (18). Arıkan ve ark. yaptığg araştırma sonucunda CAGE testinin ülkemizde alkolizm tanısı için güvenilir olarak bildirilmiştir (19). CAGE testinde 2 ve üzeri evet yanıtı alkol kötüye kullanım olarak değerlendirilmektedir.

\section{Veri Toplama}

Veriler Aile Hekimliği Polikliniğinde görevler hekim tarafından çalışmaya katılmayı kabul eden sigara veya alkol kullandığını beyan eden tüm katılımcılar ile ilgili veri toplama formları kullanılarak elde edilmiştir.

\section{Değişkenler}

Bağımsız Değişkenler: Sosyodemografik özellikler, sağlık/hastalık özellikleridir.

Bağımlı Değişkenler: Fagerström nikotin bağımlılık testi sonuçları ve CAGE alkol kötüye kullanım testi sonuçları

\section{Etik ve İzin:}

Çalışmamız Fırat Üniversitesi Tıp Fakültesi Girişimsel Olmayan Araştırmalar Etik kurulunun 20.10.2015 tarih ve 113310 sayılı etik kurul kararı ve üniversitesi hastanesi başhekimliğinden yazılı izin alındıktan sonra yapılmıştır. Anket, Şubat-Nisan 2016 tarihlerinde üç ay süreyle Aile Hekimliği Polikliniğimize başvuran hastalara uygulanmıştır. Çalışmamıza 18 yaş üzeri, sigara veya alkol kullandığını beyan eden ve anket doldurmayı kabul eden tüm gönüllüler dahil edilmiştir.

\section{Ístatistiksel analiz:}

Çalışmada elde edilen bulgular değerlendirilirken istatiksel analiz için SPSS 21.0 paket programı kullanılmıştır. Ortalamalar standart sapma ile beraber verilmiştir. İstatistiksel analizde Ki-Kare ve Fisher Ki-Kare testleri kullanılmıştır. Sonuçlar \%95'lik güven aralığında, istatistiksel anlamlılık $\mathrm{p}<0.05$ düzeyinde değerlendirilmiştir.

\section{BULGULAR}

Çalışmaya dahil edilen ve sigara kullandığını beyan 


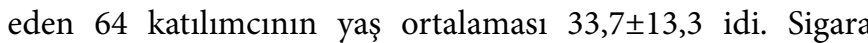
kullanan katılımcıların \% 90,6'sı erkek katılımcılar idi. Sigara kullanan katılımcıların \% 64,1'i yüksekokul ve üzeri eğitim düzeyine sahip bireylerden oluştuğu görüldü. Sosyodemografik özellikler ile sigara kullanımı ilişkisi Tablo 1'de ayrıntılı olarak verilmiştir.

Tablo 1. Sigara kullanan katılımcıların sosyodemografik özellikleri

\begin{tabular}{|c|c|c|}
\hline Özellikler & Say1 (n) & Yüzde (\%) \\
\hline \multicolumn{3}{|l|}{ Cinsiyet } \\
\hline Kadın & 6 & 9,4 \\
\hline Erkek & 58 & 90,6 \\
\hline \multicolumn{3}{|l|}{ Eğitim düzeyi } \\
\hline Lise ve alt1 & 23 & 35,9 \\
\hline Yükseköğrenim & 41 & 64,1 \\
\hline \multicolumn{3}{|l|}{ Medeni durum } \\
\hline Evli & 30 & 46,9 \\
\hline Bekar & 34 & 53,1 \\
\hline \multicolumn{3}{|l|}{ Gelir Düzeyi } \\
\hline Kötü & 11 & 17,2 \\
\hline Orta & 36 & 56,2 \\
\hline İyi & 17 & 26,6 \\
\hline \multicolumn{3}{|l|}{ En uzun yaşanılan yer } \\
\hline Köy-kasaba & 15 & 23,4 \\
\hline İlçe & 12 & 18,8 \\
\hline İl merkezi & 37 & 57,8 \\
\hline \multicolumn{3}{|l|}{ Meslek } \\
\hline Öğr.üyesi/hekim & 4 & 6,3 \\
\hline Memur & 17 & 26,6 \\
\hline Öğrenci & 22 & 34,4 \\
\hline Asgari ücretli çalışan & 19 & 29,7 \\
\hline İşsiz & 2 & 3,1 \\
\hline
\end{tabular}

Alkol kullanan katılımcıların \% 85,7'si erkek katılımcılar idi. Medeni durum ile alkol kullanım özelliğine baktı̆̆ımızda alkol kullananların \% 71,4'ü bekârlar idi. Meslek açısından baktığımızda alkol kullananların \% 43,0’’nın öğrenciler olduğu görüldü (Tablo 2).

Katılımcıların nikotin bağımlılığını ölçmek için fageström nikotin bağımlılık testi (FNBT) uygulandı. FNBT puanlarına göre katılımcılar düşük bağımlılık ve orta-yüksek bağımlılık olarak iki gruba ayrıldı. Erkeklerin \% 58,6'sı yüksek bağımlı olarak görülse de cinsiyetin bağımlılık düzeyi üzerine istatistiksel olarak anlamlı etkisi olmadığ görüldü. Lise ve altı eğitim düzeyine sahip bireylerin \% 60,9'unun bağımlılık düzeyi yüksek saptanmasına rağmen istatistiksel olarak anlamlı değildi ( $>0,05)$. Medeni durumun bağımlılık düzeyine ilişkisine baktığımızda evlilerin \% 70'lik kesiminin bağımlılık düzeyi
Tablo 2. Alkol kullanan katılımcıların sosyodemografik özellikleri.

\begin{tabular}{|c|c|c|}
\hline Özellikler & Sayı (n) & Yüzde (\%) \\
\hline \multicolumn{3}{|l|}{ Cinsiyet } \\
\hline Kadın & 4 & 14,3 \\
\hline Erkek & 24 & 85,7 \\
\hline \multicolumn{3}{|l|}{ Ĕ̆itim düzeyi } \\
\hline Lise ve alt & 7 & 25,0 \\
\hline Yükseköğrenim & 21 & 75,0 \\
\hline \multicolumn{3}{|l|}{ Medeni durum } \\
\hline Evli & 8 & 28,6 \\
\hline Bekar & 20 & 71,4 \\
\hline \multicolumn{3}{|l|}{ Gelir Düzeyi } \\
\hline Kötü & 3 & 10,7 \\
\hline Orta & 18 & 64,3 \\
\hline$\dot{I} y i$ & 7 & 15,0 \\
\hline \multicolumn{3}{|l|}{ En uzun yaşanılan yer } \\
\hline Köy-kasaba & 7 & 25,0 \\
\hline İlçe & 6 & 21,4 \\
\hline İl merkezi & 15 & 53,6 \\
\hline \multicolumn{3}{|l|}{ Meslek } \\
\hline Öğr.üyesi/hekim & 2 & 7,1 \\
\hline Memur & 6 & 21,4 \\
\hline Öğrenci & 12 & 43,0 \\
\hline Asgari ücretli çalışan & 6 & 21,4 \\
\hline$\dot{I}_{\text {Issiz }}$ & 2 & 7,1 \\
\hline
\end{tabular}

yüksek olduğu bekâr katılımcılara oranla bağımlılık potansiyeli yüzdesinin fazla olmasına rağmen istatistiksel olarak anlamlı olmadığı görüldü. Katılımcıları kendi beyanlarına göre üç gelir düzeyinde incelediğimizde gruplar arasında istatistiksel olarak anlamlı bir fark olmadı̆̆ çocukluklarını geçirdikleri yerin sigara bağımlılık düzeyi ile ilişkisine rastlanmadı. Mesleğin sigara bağımlılığ 1 ile istatistiksel olarak anlamlı bir ilişkisi olmamasına rağmen bağımlılık riskinin en yüksek olduğu grup hekim-öğretim üyesi grup iken öğrencilerin diğer gruplara nazaran bağımlılık düzeylerini daha düşük saptadık. Katılımcıların sigaraya başlama yaşının istatistiksel olarak anlamlı şekilde bağımlılık düzeyi ile ilişkili olduğu ve 15 yaşından önce sigaraya başlayanlarda bağımlılık derecelerinin daha yüksek olduğu görüldü $(p<0,05)$. Aile de sigara içen birey varlığının bağımlılık düzeyini etkilemediğini her iki grubunda benzer risk taşıdığı saptandı. Bağımlılık derecesinin sigarayı bırakma girişimine etkisinin istatistiksel olarak anlamlı olduğu düşük nikotin bağımlılarının sigarayı bırakmayı denemedikleri, yüksek bağımlılığı olanların daha fazla sigara bırakmayı deneme girişimleri olduğu fakat onlarında bağımlılık nedeni ile başarısız olduğu görüldü $(\mathrm{p}<0,05)$. Kapalı alanda sigara içme yasağı sonrası katılımcıların tutumlarını 
Tablo 3. Katılımcıların Bazı Özelliklerinin Nikotin Bağımlılık Düzeyleri ile İlişkisi

\begin{tabular}{|c|c|c|c|c|c|c|c|}
\hline \multirow[t]{2}{*}{ Özellikler } & \multicolumn{2}{|c|}{ Düşük nikotin bağımlılık } & \multicolumn{2}{|c|}{ Orta-yükseknikotin bağımlılık } & \multicolumn{2}{|l|}{ Total } & \multirow[t]{2}{*}{ İstatistik } \\
\hline & Sayı $(\mathrm{n})$ & Yüzde (\%) & Sayi (n) & Yüzde(\%) & Say1 (n) & Yüzde(\%) & \\
\hline \multicolumn{8}{|l|}{ Cinsiyet } \\
\hline Kadın & 3 & 11,1 & 3 & 8,1 & 6 & 9,4 & $\mathrm{X} 2=0,17$ \\
\hline Erkek & 24 & 88,9 & 34 & 91,9 & 58 & 90,6 & $\mathrm{P}=0,69$ \\
\hline \multicolumn{8}{|l|}{ Eğitim durum } \\
\hline Lise ve altı & 9 & 33,3 & 14 & 37,8 & 23 & 35,9 & $\mathrm{X} 2=0,14$ \\
\hline Yüksekokul & 18 & 66,7 & 23 & 62,2 & 41 & 64,1 & $\mathrm{P}=0,71$ \\
\hline \multicolumn{8}{|l|}{ Medeni durum } \\
\hline Evli & 9 & 33,3 & 21 & 56,8 & 30 & 46,9 & $\mathrm{X} 2=3,44$ \\
\hline Bekar & 18 & 66,7 & 16 & 43,2 & 34 & 53,1 & $\mathrm{P}=0,07$ \\
\hline \multicolumn{8}{|l|}{ Gelir düzeyi } \\
\hline Kötü & 4 & 14,8 & 7 & 18,9 & 11 & 17,2 & $\mathrm{X} 2=0,4,24$ \\
\hline Orta & 19 & 70,4 & 17 & 46,0 & 36 & 56,2 & $\mathrm{P}=0,33$ \\
\hline İyi & 4 & 14,8 & 13 & 35,1 & 17 & 26,6 & \\
\hline \multicolumn{8}{|c|}{ En uzun yaşadığ 1 yer } \\
\hline Köy & 7 & 25,9 & 8 & 21,6 & 15 & 23,4 & $\mathrm{X} 2=2,16$ \\
\hline İlçe & 7 & 25,9 & 5 & 13,5 & 12 & 18,8 & $\mathrm{P}=0,32$ \\
\hline İl & 13 & 48,2 & 24 & 64,9 & 37 & 57,8 & \\
\hline \multicolumn{8}{|l|}{ Meslek } \\
\hline Öğr.üyesi/hekim & 1 & 3,7 & 3 & 8,1 & 4 & 6,2 & \\
\hline Memur & 6 & 22,2 & 11 & 29,7 & 17 & 26,6 & $\mathrm{X} 2=10,59$ \\
\hline Öğrenci & 13 & 48,1 & 9 & 24,3 & 22 & 26,6 & $\mathrm{P}=0,74$ \\
\hline Asgari ücretli & 5 & 18,6 & 12 & 32,5 & 17 & 34,4 & \\
\hline Çalışmayan & 2 & 7,4 & 2 & 5,4 & 4 & 6,2 & \\
\hline \multicolumn{8}{|l|}{ Yaş } \\
\hline$\leq 40$ yaş & 19 & 70,4 & 24 & 64,9 & 43 & 67,2 & $\mathrm{X} 2=0,22$ \\
\hline$<40$ yaş & 8 & 29,6 & 13 & 35,1 & 21 & 32,8 & $\mathrm{P}=0,64$ \\
\hline \multicolumn{8}{|c|}{ Sigara başlama yaşı } \\
\hline$<15$ yaş & 5 & 18,5 & 16 & 43,2 & 21 & 32,8 & $\mathrm{X} 2=4,33$ \\
\hline$\geq 15$ yaş & 22 & 81,5 & 21 & 56,8 & 43 & 67,2 & $\mathrm{P}=0,03$ \\
\hline \multicolumn{8}{|c|}{ Ailede sigara içen birey durumu } \\
\hline Var & 19 & 70,4 & 26 & 70,3 & 45 & 70,3 & $\mathrm{X} 2=0,01$ \\
\hline Yok & 8 & 29,6 & 11 & 29,7 & 19 & 29,7 & $\mathrm{P}=0,99$ \\
\hline \multicolumn{8}{|c|}{ Birakmayı deneme } \\
\hline Evet & 6 & 22,2 & 23 & 62,2 & 29 & 45,3 & $\mathrm{X} 2=10,05$ \\
\hline Hayır & 21 & 77,8 & 14 & 37,8 & 35 & 54,7 & $\mathrm{P}=0,02$ \\
\hline \multicolumn{8}{|l|}{$\begin{array}{l}\text { Yasak sonrası } \\
\text { içme davranış1 }\end{array}$} \\
\hline Azaldı & 9 & 33,3 & 5 & 13,5 & 14 & 21,9 & $\mathrm{X} 2=3,59$ \\
\hline Değişmedi & 18 & 66,7 & 32 & 86,5 & 50 & 78,1 & $\mathrm{P}=0,05$ \\
\hline \multicolumn{8}{|l|}{$\begin{array}{l}\text { Kamu spotlarının } \\
\text { etkisi }\end{array}$} \\
\hline Yararsiz & 8 & 32,0 & 28 & 71,8 & 36 & 56,2 & $\mathrm{X} 2=9,80$ \\
\hline Yararlı & 17 & 68,0 & 11 & 28,2 & 28 & 43,8 & $\mathrm{P}=0,02$ \\
\hline
\end{tabular}


sorguladığımızda bağımlılık düzeyi yüksek olanların \% 64’ünün sigara kullanımında değişiklik olmadığı ve yasaktan etkilenmediği görüldü. Katılımcılara kamu spotlarının sigara ile olan mücadeleye yararını sorguladığımızda ise istatistiksel olarak anlamlı şekilde yararı olmadığı özellikle nikotin bağımlılık düzeyi yüksek olan katılımcıların \% 77,8'i yararının olmadığını belirtmiştir (Tablo 3).

Alkol kullananların CAGE toplam puanları incelenince $\%$ 47.3'ünün puanı 1, \% 17.9'unun puanı 0, \% 17.9'unun 2 ve $\% 17,9$ 'unun puanı 3 olarak saptand. CAGE testinden en yüksek puan olan 4 puan alan katılımcıya rastlanmadı. Tüm katılımcıların \% 35,7'sinin CAGE puanı 2 ve üzerinde saptandı. Katılımcıların tükettikleri alkol sorgulamasında \% 35,7 ile en sık votka tüketildiğini \% 28,6'lık kullanım sıklığı ile rakının votkadan sonra en sık kullanılan alkol türü olduğu görüldü. Katılımcıların \% 50'sinin ayda bir kez alkol aldığı ve haftada 4 ve üzeri sıklıkta alkol alım oranının \% 17,9 olduğu görüldü. (Tablo 4)

Tablo 4. Alkol kullanımı ile ilgili bazı değişskenlerin dağılımı

\begin{tabular}{|l|l|l|}
\hline Özellikler & Say1 & Yüzde \\
\hline Toplam CAGE puanı & 5 & 17,9 \\
\hline 0 & 13 & 47,3 \\
\hline 1 & 5 & 17,9 \\
\hline 2 & 5 & 17,9 \\
\hline 3 & 5 & 0 \\
\hline 4 & 0 & 50,0 \\
\hline Kullanım sıklı̆̆1 & \multicolumn{2}{|l|}{} \\
\hline Ayda 1 & 14 & 17,9 \\
\hline Ayda 2-3 kez & 5 & 14,2 \\
\hline Haftada 2-3 kez & 4 & 17,9 \\
\hline Haftada 4 ve üzeri & 5 & \\
\hline Kullanılan alkolün cinsi & \multicolumn{2}{|l|}{} \\
\hline Rak1 & 8 & 28,6 \\
\hline Bira & 6 & 21,5 \\
\hline Şarap & 2 & 7,1 \\
\hline Cin & 2 & 7,1 \\
\hline Votka & 10 & 35,7 \\
\hline Tek seferde tüketilen alkol miktarı \\
\hline 1 standart ölçü & 6 & 21,4 \\
\hline 2 standart ölçü & 8 & 28,7 \\
\hline 3 standart ölçü & 2 & 7,1 \\
\hline 4 standart ölçü ve üzeri & 2 & 7,1 \\
\hline 5 standart ölçü ve üzeri & 10 & 35,7 \\
\hline
\end{tabular}

Araştırmamızda alkole başlama yaş ortalaması 18,8 $\pm 3,6$ olarak bulundu. Alkole başlama yaşının CAGE puanı ile istatistiksel olarak anlamlı bir ilişsisi olmasa da düşük bağımlılık düzeyine sahip olan bireylerin $\% 72,2$ 'sinin 18 yaşından önce alkole başlayan bireyler olduğu görüldü. Katılımcıların \% 32,1'inin ailelerinde alkol kullanım öyküsü mevcuttu. CAGE puanının sosyodemografik özellikler ile ilişkisine baktığımızda CAGE puanı 2 ve üzerinde olanların \% 90,0'1 erkek katılımcilar idi. Lise ve altı bireylerde alkol kullanımı daha sık iken yüksekokul ve üzeri eğitim düzeyine sahip bireylerin \% 38,1'inin CAGE puanının 2'nin üzerinde olduğu ve alkol kötüye kullanımının eğitim düzeyi arttıkça arttı̆̆ 1 görüldü. Medeni durum ve gelir düzeyinin etkisine batığımızda evlilerin \% 50,0'1 ve orta gelir düzeyine sahip bireylerin \% 44,4'ü alkol kötüye kullanım oranı ile diğer katılımcılardan yüksek saptandı. Ailede alkol kullanan birey varlığ 1 incelendiğinde alkol kullanan 28 katılımcının \% 32,1'i ailede alkol kullanan birey olduğunu ifade etmiştir. Alkol kullanan katılımcıların yaşlarının ve kullanım sürelerinin bağımlık düzeylerine etkisine baktığımızda ise 40 yaş üzeri katılımcıların \% 37,5'inin CAGE puanın 2 ve üzerinde olduğu ve istatistiksel değerlendirme yapılamamasına rağmen kullanım süresi ve ileri yaşın bağımlılık ile ilgili olduğu görüldü. Katılımcıların \% 42,9'u alkolü bırakmayı düşündüğü görüldü. Bağımlılık düzeyi ile alkolü bırakmayı düşünme arasında istatistiksel olarak ilişki saptanmadı fakat alkolü bırakmayı düşünenlerin \% 41,7’si yüksek bağımlılar iken bırakmayı düşünmeyen grubun \% 68,8'ini düşük bağımlılar oluşturmakta idi. Katılımciların tek seferde tükettikleri alkol miktarı arttıkça CAGE puanının arttığı görüldü. CAGE puanı 2 ve üzerinde olan katılımciların tamamı tek seferde 4 standart içki birimi üzerinde tüketen katılımcılar idi (Tablo5).

\section{TARTIŞMA}

Literatür verilerinde nikotin bağımlılı skoru arttıkça sigara bırakmanın zorlaştı̆̆ 1 ve sigara bıraktırma tedavisi alanlarda ise replasman tedavisi ve ilaç dozlarının ayarlanması gerekliliği vurgulanmıştır $(20,21)$. Bu bağlamda araştırmamızda FNBT kullanılarak katılımcıların nikotin bağımlılık düzeyleri ölçülmüsştür. Sigara kullandığını beyan eden katılımcllardan \% 25'inin yüksek nikotin bağımlısı olduğu görüldü. Ülkemizde yapılan araştırmaları incelediğimizde Okutan ve ark. \% 24,9, Deveci ve ark. \% 21,8 oranında yüksek nikotin bağımlılığı oranları bildirmişlerdir ve elde ettiğimiz bulgular benzer popülasyonda yapılan araştırmalarla uyumlu bulunmuştur $(22,23)$. Ülkemizde Buturak ve ark. \% 40,4, Örsel ve ark. \% 34 oranında bildirdiği yüksek nikotin bağımlılık oranları sigara bıraktırma polikliniğinde yapılan araştırmalar olmasından dolayı elde ettiğimiz \% 25'lik yüksek nikotin bağımlılık oranlarından yüksek veriler olduğu düşünülmüştür $(3,24)$. Bizim araştırmamız ve genel popülasyonlarda yapılan benzer araştırmalar yüksek nikotin bağımlılı̆̆ının her dört sigara kullanıcısından birinde görüldüğünü göstermiştir.

Nikotin bağımlılık düzeyine etki eden faktörleri incelediğimizde erkek cinsiyette yüksek nikotin bağımlılık oranının kadınlardan istatistiksel olarak anlamlı olarak fazla olduğu görülmüsstür. Literatür verileri incelediğinde ülkemizde Örsel, Şengezer ve Kaya tarafından yapılan üç ayrı incelemede elde ettiğimiz bulgularla benzer şekilde erkeklerde yüksek nikotin bağımlılık oranları kadınlardan fazla saptanmıştır (3, 25 , 26). Genel popülasyonda yapilan iki ayrı çalışmada ise cinsiyet ile nikotin bağımlılık derecesi arasında istatistiksel olarak anlamlı bir iliş̧i olmadığı bildirilmiştir $(22,27)$. Buturak ve ark. ise bulgularımızın aksine kadınlarda ağır sigara içiciliği oranını erkelerden yüksek bildirmişlerdir (24). Buturak ve ark. bulgularının verilerimiz ile çelişkili olması çalışmanın sigara bıraktırma polikliniğine başvuran sigara bıraktırma tedavisi alan hastalar arasında yapılmasından kaynaklanabileceği düşünülmüştür. Sigara kullanan katılımcılar arasında kadın sayısının azlığı araştırmamızın kısıtlılıkları arasında değerlendirilebilir ve cinsiyet ile bağımlılık düzeyi arasındaki ilişkinin daha geniş çaplı araştırmalarla incelenmesinin literatüre daha fazla katkı sağlayabileceği düşünülmüştür. 


\section{Tablo 5. Sosyodemografik özelliklerin alkol bağımlılı düzeyi ile ilişkisi.}

\begin{tabular}{|c|c|c|c|c|c|c|}
\hline \multicolumn{7}{|l|}{ CAGE PUANI } \\
\hline Özellikler & \multicolumn{2}{|c|}{ CAGE 2'nin alt1 } & \multicolumn{2}{|c|}{ CAGE 2'nin üzeri } & \multicolumn{2}{|c|}{ Toplam } \\
\hline \multicolumn{7}{|l|}{ YAŞ } \\
\hline$<40$ yaş & 13 & 72,2 & 7 & 70,0 & 20 & 71,4 \\
\hline$\geq 40$ yaş & 5 & 27,8 & 3 & 30,0 & 8 & 28,6 \\
\hline \multicolumn{7}{|l|}{ Başlama yaşı } \\
\hline$<18$ yaş & 13 & 72,2 & 2 & 20,0 & 15 & 53,6 \\
\hline$\geq 18$ yaş & 5 & 27,8 & 8 & 80,0 & 13 & 46,4 \\
\hline \multicolumn{7}{|l|}{ Cinsiyet } \\
\hline Kadın & 3 & 16,7 & 1 & 10,0 & 4 & 14,3 \\
\hline Erkek & 15 & 83,3 & 9 & 90,0 & 24 & 85,7 \\
\hline \multicolumn{7}{|l|}{ Eğitim durumu } \\
\hline Lise ve alt1 & 5 & 27,8 & 2 & 20,0 & 7 & 25,0 \\
\hline Yükseköğrenim & 13 & 72,2 & 8 & 80,0 & 21 & 75,0 \\
\hline \multicolumn{7}{|l|}{ Medeni durum } \\
\hline Evli & 4 & 22,2 & 4 & 40,0 & 8 & 28,6 \\
\hline Bekar & 14 & 77,8 & 6 & 60,0 & 20 & 71,4 \\
\hline \multicolumn{7}{|l|}{ Gelir düzeyi } \\
\hline Kötü & 3 & 16,7 & 0 & 0,0 & 3 & 10,7 \\
\hline Orta & 10 & 55,5 & 8 & 80,0 & 18 & 64,3 \\
\hline İyi & 5 & 27,8 & 2 & 20,0 & 7 & 25,0 \\
\hline \multicolumn{7}{|l|}{ Meslek } \\
\hline Öğretim üyesi & 1 & 5,5 & 1 & 10,0 & 2 & 7,1 \\
\hline Memur & 3 & 16,7 & 3 & 30,0 & 6 & 21,5 \\
\hline Öğrenci & 8 & 44,5 & 4 & 40,0 & 12 & 42,8 \\
\hline Asgari ücretli & 5 & 27,8 & 1 & 10,0 & 6 & 21,5 \\
\hline Çalışmayan & 1 & 5,5 & 1 & 10,0 & 2 & 7,1 \\
\hline \multicolumn{7}{|c|}{ En uzun yaşadığı yer } \\
\hline Köy & 3 & 16,7 & 4 & 40,0 & 7 & 25,0 \\
\hline İlçe & 3 & 16,7 & 3 & 30,0 & 6 & 21,4 \\
\hline İl & 12 & 66,6 & 3 & 30,0 & 15 & 53,6 \\
\hline \multicolumn{7}{|c|}{ Ailede alkol kullanım öyküsü } \\
\hline Var & 7 & 38,9 & 2 & 20,0 & 9 & 32,1 \\
\hline Yok & 11 & 61,1 & 8 & 80,0 & 19 & 67,9 \\
\hline \multicolumn{7}{|c|}{ Alkolü bırakmayı deneme } \\
\hline Evet & 7 & 38,9 & 5 & 50,0 & 12 & 42,9 \\
\hline Hayır & 11 & 61,1 & 5 & 50,0 & 16 & 57,1 \\
\hline \multicolumn{7}{|c|}{ Tek seferde tüketilen alkol miktarı } \\
\hline 3 birim ve alt1 & 16 & 88,9 & 0 & 0,0 & 16 & 57,1 \\
\hline 4 birim ve üzeri & 2 & 11,1 & 10 & 100,0 & 12 & 42,9 \\
\hline
\end{tabular}

Araştırmamızda nikotin bağımlılık düzeyinin eğitim seviyesi, medeni durum, gelir düzeyi, meslek ve kişinin büyüdüğü yer gibi sosyodemografik özellikleri açısından istatistiksel olarak anlamlı bir ilişkisi olmadığ görülmüştür. Ülkemizde yapılan bazı araştırmalarda yaş, medeni durum, eğitim düzeyi ve gelir düzeyinin bağımlılık derecesini etkilemediği bildirilmiştir ve elde ettiğimiz bulgular ile benzer sonuçlar bildirilmiştir $(22,28)$. Araştırmamızda istatistiksel olarak anlamlı olmamakla birlikte eğitim düzeyi düşük olanlarda ve asgari ücretle çalışan katılımcılarda yüksek nikotin bağımlılık oranının fazla olduğu görülmüştür. $\mathrm{Bu}$ bağlamda literatürü incelediğimizde Şengezer ve ark. yaptığı çalışmada asgari ücretli çalışanlarda sigara kullanım sıklığının ve bağımlılığının yüksek olduğunu, Buturak ve ark. yaptığı çalışmada ise lise ve altı düşük eğitim seviyesine sahip bireylerde ağır sigara içiciliğinin \% 58 oranında diğer gruplardan fazla 
olduğunu saptamışlar ve elde ettiğimiz verilere benzer veriler bildirmişlerdir $(24,25)$.

Araştırmamızda düşük nikotin bağımlılık düzeyine sahip katılımcıların büyük oranda öğrencilerden oluştuğu dikkatimizi çekmiştir. Çapık ve ark. öğrenciler arasında yaptığı bir araştırmada sigara kullanan öğrencilerin \% 62,5 oranında düşük nikotin bağımlılık düzeyine sahip olduklarını ama okul yılları arttıkça nikotin bağımlılık düzeyinin arttı̆̆ını bildirmişlerdir (28). Nikotin bağımlılık düzeyi arttıkça sigara bırakmanın zorlaştığı göz önüne alınırsa öğrencilerin bu erken evrede müdahale edilerek yüksek bağımlılık kazanmadan sigara bıraktırma konusunda önlemler alınabileceği düşünülmüştür.

Ailede sigara kullanan birey varlı̆̆ı, sigarayı bırakmayı deneme, kapalı alanda sigara içme yasağı ve kamu spotlarının kişiler üzerindeki etkisi ile nikotin bağımlılık derecesi arasında anlamlı istatistiksel bir ilişkiye rastlanmamıştır. Literatür verilerinde ailede sigara kullanan birey varllğı sigara kullanım riskini arttırdığına yönelik bulgular mevcut olmasına rağmen konunun bağımlılık derecesi ile ilişkisine vurgu yapılmadığı görülmüştür (22). Nikotin bağımlılık derecesinin ailede sigara kullanan birey varlığından etkilenip etkilenmediği daha kapsamlı araştırmalar ile incelenmesi gerektiği düşünülmüştür. Literatür verilerinde sigarayı bırakmayı denemenin nikotin bağımlılığı ile ilişkisine vurgu yapılan çalışmaları incelediğimizde bırakmayı deneme girişimlerinin yüksek bağımlılarda daha fazla olduğu fakat sigarayı bırakmanın ise zorlaştığı bildirilmiştir. Literatür bulguları 1şı̆̆ında araştırmamızda sigarayı bırakmayı hiç düşünmediğini bildiren katılımcıların yarısının düşük nikotin bağımlılık düzeyine sahip olması literatür verileri ile uyumlu ve ilgi çekici bulunmuştur. Buradan elde ettiğimiz bulgulara dayanarak sigara bıraktırma yöntem ve tedavilerinin daha etkili olduğu grup olan düşük nikotin bağımlısı katılımcıların sigarayı bırakmayı düşünmeye sevk etmemiz sigara ile mücadelede bizlere önemli bir kazanım sağlayabileceği düşünülmüştür $(22,23)$.

Sigara ile mücadele yöntemlerinden birisi olan kamu spotlarının katılımcllarımız üzerindeki etkisini incelediğimizde düşük nikotin bağımlılığına sahip bireylerin \% 62,5'lik büyük kısmı sigara ile mücadelede yararlı olduğunu belirtmişlerdir. Yıldırım ve ark. tarafından yapılan araştırmada sigara paketleri üzerindeki yazıların caydırıcılığı katılımcılara sorulmuş ve sigara kullananların sadece \%20'si etkili olabileceğini beyan etmiştir (29). Aynı çalışmada sigara içmeyenlerin ise $\% 75^{\prime} \mathrm{i}$ bu uyarıların etkili olabileceğini beyan etmesi nikotin bağımlılık derecesi ve kamu spotlarının etkinliği arasında zıt bir ilişki olduğunu düşündürmüştür. Nikotin bağımlılığı sigarayı bıraktırmayı zorlaştırdığı gibi sigara ile mücadele yöntemlerinin etkinliğinin de azaltabileceği düşünülmüştür.

Literatür verileri incelendiğinde yaş arttıkça nikotin bağımlılık derecesinin arttığı bildirilmiştir $(22,27)$. Araştırmamızda yaş ile nikotin bağımlılık derecesi arasında istatistiksel olarak anlamlı bir ilişki olmamasına rağmen düşük nikotin bağımlısı olan 27 katılımcının 20 'sinin 40 yaş altındaki katılımcılar olması literatür verileri ile benzerlik göstermiştir. Sigaraya başlama yaşı ve sigara kullanım süresi dikkate alındığında daha yaşlı bireylerde nikotin bağılılık düzeylerinin yüksek saptanmasının elde ettiğimiz verileri anlamlı kıldığı düşünülmüştür.

Literatürde bir diğer önemli nikotin bağımlllık düzeyini etkileyen unsurun kişilerin sigaraya başlama yaşı olduğu bildirilmiştir. Sigaraya başlama yaşı düștükçe nikotin bağımlılık düzeylerinin arttığı tespit edilmiştir (22, 30). Bu bağlamda araştırmamızda sigara başlangıç yaşı ile nikotin bağımlılık düzeyi arasındaki ilişkiye baktığımız da 15 yaşından önce sigaraya başlayanlarda nikotin bağımlılık düzeyinin daha yüksek saptanmıştır. Bu bulgular bir kez daha sigara ile mücadelenin erken yaşlarda başlaması gerektiğini düşündürmüştür.

Araştırmamızın bir diğer amacı ise alkol kötüye kullanım durumunun sorgulanması ve etkileyen faktörlerin araştırılması idi. Araştırmamızda alkol kullanım oranı \% 13,3 olarak tespit edildi. Ülkemizde yapılan iki ayrı çalışmada alkol kullanım oranı genel popülasyonda yapılan çalışmada $\% 18$ ve üniversite öğrencileri arasında yapılan araştırmada ise \% 10,2 olarak bildirilmiştir $(26,30)$. Araştırmamız bir üniversite hastanesi polikliniğinde yapıldığından katılımcılar arasında hem genel popülasyon, hem de öğrencilerin olduğu düşünüldüğünde elde ettiğimiz \% 13,3'lük alkol kullanım oranı literatür ile uyumlu olarak değerlendirilmiştir.

Cinsiyetin alkol kullanım üzerine etkisine baktığımızda literatür verileri ve bulgularımız erkeklerde alkol kullanımının daha fazla olduğunu göstermiştir (26). Emeç ve ark. tarafından TUIK verileri incelenerek yapılan araştırmada genel popülasyonda eğitim seviyesi ve gelir düzeyi arttıkça alkol tüketiminin de arttığı bildirilmiştir (31). Araştırmamızda eğitim düzeyi arttıkça alkol kötüye kullanım oranlarının arttığı görülmüştür. Literatür verileri ve elde ettiğimiz bulgular alkol kötüye kullanımında gelir düzeyinin ve eğitim seviyesinin etkili olduğunu düşündürmüştür. Araştırmamamızda evli bireylerde alkol kötüye kullanım oranının daha yüksek olduğu tespit edilmiştir. Literatür verileri incelendiğinde Evren ve ark. alkol bağımlılığı tanısı konanların \% 76'sının evli olduğunu, madde bağımlılı̆̆ı tedavisi gören kişilerde ise bekarların daha yüksek oranda olduğu bildirilmiştir. Genel popülasyonda yapılan bir diğer araştırmada ise bekarlarda kötüye kullanım oranının daha yüksek olduğu bildirilmiştir $(32,33)$. Medeni durumun alkol kullanım durumuna etkisinin, araştırmanın yapıldığı popülasyona göre değiştiği ve aradaki ilişkinin daha net aydınlatılabilmesi için geniş çaplı araştırmalara ihtiyaç olduğu düşünülmüştür.

Gaziosmanpaşa ve Akdeniz Üniversitelerinde yapilan iki ayrı çalışmada ailede alkol kullanan birey varlığının alkol kullanımını arttırdığı bildirilmiştir $(34,35)$. Araştırmamızda alkolkullanan herikibireydenbirisiailedealkolkullanan yakının olduğunu beyan etmiştir. Öztürk ve ark. ailede alkol kullanan birey bulunması beraberinde aile içi şiddeti arttırdığı ve bireyleri alkol kullanmaya ittiğini bildirmişlerdir (36). Araştırmamızda aile içi ilişkilerin sorgulanmaması araştırmamızın bu konu hakkında yetersiz kaldığını göstermiştir. Ailede alkol kullanan birey varlığ ilerleyen yaşamlarında alkol kullanma durumlarına etkisinin güncel çalışmalar ile araştırılması gerektiği düşünülmüştür. Sigarada olduğu gibi alkolde de 40 yaş üzeri bireylerde kötüye kullanım oranı yüksek bulunmuştur. Emeç ve ark. 35-65 yaş aralı̆̆ındaki bireylerin 25-35 yaş aralığındaki bireylere nazaran daha fazla alkol kullandıklarını bildirişlerdir (31). Bu bulgular sigarada olduğu gibi alkol kullanımı ile olan mücadelede de erken yaşların önemli olduğunu düşündürmüştür.

CAGE alkol bağımlılık puanlarına etki eden faktörlere baktığımızda literatürde alkol kullanım sıklı̆̆ ve tek seferde tüketilen alkol miktarının fazlalığının etkili olduğu bildirilmiştir 
(32). Araştırmamızda da literatür ile benzer şekilde tek seferde tüketilen alkol miktarı arttıkça CAGE bağımlılık puanlarının artış gösterdiği saptanmıştır.

Kisıtlılıklarımız: Her ne kadar araștırmamız polikliniğimize başvuran hastalarda yapılmış olsa da katılımcı sayısının azlığı elde ettiğimiz verilerin genel popülasyona yorumlanmasında kısıtlılıklara sebep olduğu düşünülmüştür. Özellikle alkol kullanan katılımcı sayısında ki azlık alkol kötüye kullanımını etkileyen faktörleri analiz etmemizi zorlaştırmıştır. Tüm bu kısitlllıklara rağmen alkol ve sigara bağımlılığının günümüzde önemli bir sorun olduğu ve güncel araştırmalar ile konunun önemi vurgulanarak yeni çözüm yollarının araştırılması gerektiği kanaatindeyiz.

Sonuç: Sigara ve alkol ile mücadeleye rağmen her iki maddenin kullanım ve bağımlılık oranları toplum sağlı̆̆ını tehdit etmeye devam etmektedir. Nikotin ve alkol bağımlılık seviyelerinin sigara ve alkol kullanım özelliklerini etkilemesinin yanında insanların sigara ve alkol bırakma tedavisini zorlaştıran etkenlerin başında geldiği görülmektedir. Sigara ve alkol kullanımına yönelik mücadelede bu maddelere olan bağımlılık düzeylerinin mutlaka göz önüne alınması ve kişilerin bağımlılık derecelerine göre kişisel yaklaşımlar sergilenmesi daha etkin mücadelede anahtar rol oynayabileceği kanaatindeyiz.

Çıkar çatışması: Yoktur.

Finansal destek: Yoktur

\section{KAYNAKLAR}

1. World Health Organization. World Health Statistics. http://www.euro.who.int/en/health-topics/disease-prevention/tobacco Erişim tarihi:19,08,2018

2. Türkiye İstatistik Kurumu (TUIK). Küresel Yetişkin Tütün Araştırması 2012. http://www.tuik.gov.tr/PreHaberBultenleri. do?id=13142. Erişim Tarihi: 25 Mayıs 2013.

3. Örsel O, Örsel S, Alpar S, Uçar N, Fırat Güven S, Şipit T, ve ark. Sigara birakmada nikotin bağımlılık düzeylerinin tedavi sonuçlarına etkisi. Solunum Hastalıkları 2005; 16: 112-118

4. Teneggi V, Squassante L, Iavarone L, Milleri S, Bye A, Gomeni R. Correlation and predictive performances of saliva and plasma nicotine concentration on tobacco with drawal-induced craving. Br J Clin Pharmacol 2002; 54: 407-14.

5. Aşut Ö. Hekim ve Sigara. 2.Bask1, Ankara. Türk Tabipler Birliği Yayınları, Maya Matbaacılık Yayıncılık Ltd. Şti. 1995.

6. Kanıt L, Keser A. Tütün bağımlılığının biyofizyolojisi. In: Aytemur ZA, Akçay Ş, Elbek O. Tütün ve tütün kontrolü. Türk Toraks Derneği, Toraks Kitapları 2010;10:141-156.

7. Benowitz NL, Hukkanen J, Jacob P. Nicotine chemistry, metabolism, kinetics and biomarkers. Handb Exp Pharmacol 2009; 192: 29-60.

8. Hughes J. Nicotine-related disorders. In: Kaplan \& Sadock's Comprehensive Textbook of Psychiatry. SAdock BJ, Sadock VA, Ruiz P (eds.). 8th ed. Philadelphia USA : Lippincott, Williams \& Wilkins; 2006: 1257-64.
9. Kandel D, Chen K, Warner LA, Kessler RC, Grant B. Prevalence and demographic correlates of symptoms of last year dependence on alcohol, nicotine, marijuana and cocaine in the U.S. population. Drug Alcohol Depend 1997; 44: 11-29.

10. Vardar E. Riskli alkol tüketme davranışının tanımı ve özellikleri. Journal of Dependence 2016; 17:123-9

11. Altıntoprak E, Annette-Akgür S, Yüncü Z, Sertöz OO, Coşkunol H. Alcohol use-related problems in women. Turk Psikiyatri Derg 2008;19: 197-208.

12. Eraslan D, Kanyılmaz S, Öztürk Ö. Exercise in the treatment of alcohol dependence. Journal of Dependence 2014; 15: 180-184

13. Wechsler H, Moeykens B, Davenport A, Castillo S, Hansen J. The adverse impact of heavy episodic drinkers on other college students. J Stud Alcohol 1995; 56: 628-634.

14. O’Malley PM, Johnston LD. Epidemiology of alcohol and other drug use among american college students. J Stud Alcohol 2002; 14: 23-39.

15. Gürdil G. Üniversite Öğrencilerinde Travma Yaşantısı, Stresle Başa Çıkma Tarzları ve İç-Dış Kontrol Odağı İnanc1 ile Riskli Alkol Kullanımı Arasındaki İlişki. Yayınlanmamış Yüksek Lisans Tezi, Ankara, Hacettepe Üniversitesi, Sosyal Bilimler Enstitüsü, 2007.

16. Özen Ş, Arı M, Gören S, Palancı Y, Sır A. Tıp fakültesi birinci ve altıncı sınıf ögrencilerinde sigara ve alkol kullanım sıklığı. Anatolian Journal of Psychiatry 2005; 6: 92-98

17. Uysal MA, Kadakal F, Karsidag C, Bayram G, Uysal O, Yilmaz V. Fagerstrom test for nicotine dependence: reliability in a Turkish sample and factor analysis. Tuberk Toraks. 2004; 52: 115-21.

18. Ewing JA. Detecting alcoholism: the CAGE questionnaire. JAMA 1984 ; 252: 1905-7.

19. Arıkan Z, Özdemir YD, Candansayar S, Işık E. SMAST ve CAGE tarama testlerinin alkolizmin tanısal önemi üzerine bir çalışma. 27. Ulusal Psikiyatri Kongresi, Antalya, 1991.

20. Heathorn TF, Kozlowski LT, Frecker RC, Fagerstrom KO. The Fagerstrom test for nicotine dependence: A revision of the Fagerstrom tolerence questionnarie. Br J Addict 1991; 86: 1119-27.

21. Haddock CK, Lando H, Klesges RC, Talcott GW, Renaud EA. A study of the psychometric and predictive properties of the FagerströmTest for Nicotine Dependence in a population of young smokers. Nicotine Tob Res 1999; 1: 59-66.

22. Okutan O, Taş D, Kaya H, Kartaloğlu Z. Sigara içen sağlik personelinde nikotin bağımlılık düzeyini etkileyen faktörler. Tüberküloz ve Toraks Dergisi 2007; 55: 356-63

23. Deveci SE, Güler H, Deveci F, Açık Y, Muz MH. Elazığ emniyet teşkilatı personelinin sigara içme davranışları, bağımlılık düzeyleri ve sigara-sağlık ilişkisine yaklaşımları. Solunum Hastalıkları 2005; 16: 12-17

24. Buturak ŞV, Günal N, Özçiçek G, Özdemir Rezaki H, Koçak OM, Kırıcı G, et al. Sigara bırakma polikliniğine başvuran hastaların sosyodemografik özellikleri ve sigara bağımlılık şiddetleri. Turk J Clin Lab 2016; 7: 72-76. 
25. Fagerstrom KO, Kunze M, Schoberberger R, Breslau N, Hughes JR, Hurt RD, et al. Nicotine dependence versus smoking prevalence: Comparisons among countries and categories of smokers. Tob Control 1996;5:49-51.

26. Russell MA, Stapleton JA, Feyerabend C, Wiseman SM, Gustavsson G, Sawe U, et al. Targeting heavy smokers in general practice: Randomized controlled trial of transdermal nicotine patches. British Medical J 1993; 306:1308-12.

27. Çelepkolu T, Atli A, Palancı Y, Yılmaz A, Demir S, İbiloğlu AO, ve ark. Sigara kullanıcılarda nikotin bağımlılık düzeyinin yaş ve cinsiyetle ilişkisi: Diyarbakır örneklemi. Dicle Tip Dergisi 2014; 41: 712-6.

28. Çapık C, Cingil D. Hemșirelik Öğrencilerinde Sigara Kullanımı, Nikotin Bağımlılık Düzeyi ve İlișkili Etmenler. Kafkas J Med Sci 2013; 3: 55-61

29. Şengezer T, Sivri F, Dilbaz N, Sunay D. Ankara ili Yenimahalle ilçesinde birinci basamak sağlık kuruluşuna başvuran bireylerde tütün bağımlılığı ve ilişkili risk faktörleri. Turk Aile Hek Derg 2014; 18: 95-97

30. Önsüz MF, Topuzoğlu A, Algan A, Soydemir E, Aslan İ. Sigara içen hastaların sigara paketlerinin üzerindeki uyarı yazıları hakkındaki görüşlerinin ve nikotin bağımlılık derecelerinin değerlendirilmesi. Marmara Medical Journal 2009; 22; 111-22
31. Yıldırım Ç, Çelik P, Şakar A, Dinç G. Tıp Fakültesi öğrencilerinin sigaraya karşı tutumları. Solunum 2004; 6: 30-5.

32. Pektaş Ö, Mırsal H, Kalyoncu A, Tan D, Beyazyürek M. Psikiyatri kliniğinde yatan hastalarda alkol kullanımı. Anadolu Psikiyatri Dergisi 2003; 4: 26-9

33. Kaya N, Cilli AS. Universite oğrencilerinde nikotin, alkol ve madde bağımlılığının 12 aylık yaygınlığı. Bağımlılık Dergisi 2002; 3: 91-97.

34. Emeç H, Gülay E. Alkol tüketimi ve sosyo-demografik değişkenlerin alkol tüketimi üzerine etkisi. Ekonomik Yaklaşım, 2008; 19: 115-34.

35. Turan M, Çilli AS, Aşkın R, Herken H, Telcioğlu M, Kucur R. Cage testi ile alkol kullanımı üzerine epidemiyolojik bir çalışma. Klinik Psikiyatri Dergisi, 1999; 2: 217-221

36. Evren EC, Saatçioğlu Ö, Evren B, Yancar C, Eken B, Çakmak D. Madde kullanım bozukluğunda cinsiyet farklılığı: AMATEM'e yatan hasta verilerinin incelenmesi. Düşünen Adam: Psikiyatri ve Nörolojik Bilimler Dergisi 2003; 16: 132-8. 